\title{
Exploring the Development of Contemporary Chinese Flute Art Through Heavenly Tune of Chinese Flute and The Ancient Call
}

\author{
Xiaojun Wu \\ School of Oriental and African Studies, University of London, London, UK \\ Email: wuxiaojun1909@yeah.net
}

\begin{abstract}
In the 21st century, the development of the flute follows the steps of modernization closely, and a batch of outstanding works with novel genre and innovative theme appear. This paper will focus on two new national art funded projects in China. One is the large humanity art epic The Ancient Call by Chinese Flute music college professor Zhang Weiliang from China Conservatory of Music, and the other is Tang Junqiao's Chinese Flute stage play Heavenly Tune of Chinese Flute. This paper aims to explore the motivation that China's performance composers create and promote the innovation of the traditional music, innovate the artistic features of Chinese Flute works, and analyze the improvement of the Chinese Flute performance art as well as the possibility of future development.

Keywords: Chinese Flute, traditional instrument, music aesthetic, music development
\end{abstract}

\section{Background}

Chinese Flute, also known as dizi, is a national musical instrument of the Han nationality. It is made of natural bamboo. Meanwhile, it is hollow inside and cylindrical outside, and there are six sound holes, one blow hole and one hole film on the Chinese Flute. The membrane on the second hole at the left end and the vibrating sound during flute blowing give it a unique timbre (Lau, 1996). Although Chinese Flute has a long history, most traditional flute works came in the 1950s. Originally, Chinese Flute was only used as an accompaniment musical instrument or principal music instrument in the band. However, under the efforts of the older generation of flute players, including Feng Zicun, Zhao Songting, Liu Guanyue, Lu Chunling and Kong Jianhua, it appeared on the stage of instrumental solo (Lau, 1996). Early flute works were categorized by region. Due to the differences between the north and south in geography, people's lifestyles and cultures make southern and northern flute songs totally different. When the northern and southern flute songs reached the peak, a batch of new flute songs with both southern and northern styles and techniques emerged. In modern times, the introduction of western music composition theory brought Chinese Flute art into a new development stage. On the basis of inheriting fine traditional folk music, flute players who have come into contact with western composition theory broadened their thinking and created more popular classical works (Zhang Weiliang, 2011). On the other hand, the flute concertos created by professional composers challenged the technical difficulty of traditional flute music and fully developed the musical expressiveness of flute. More forms of flute music creation have also blossomed, and the flute cooperates with symphony, electronic music, or the flute works cooperating with jazz-style, musical-performance appeared one by one. Zhang Weiliang generalized the development of Chinese Flute art after the 1950s into three stages, including "northern and southern school", "northern and southern fusion", "three in one of norther and southern and western music system".

The reasons why the two projects are compared in this paper are as follows. First of all, they both represent the latest achievements in the development of Chinese Flute performance art, which is of great reference value to the analysis of Chinese modern art creation concept. Secondly, they both are the national endowment for the arts program. In the selection regulations, it is clearly stipulated that the funding objects should be stage arts with high aesthetic value, artistic taste and artistic personality, profound thoughts, exquisite art as well as excellent production. Among them, it is most difficult to define aesthetic value standard. What is high aesthetic value? Through studying the following two works, this paper will try to explore.

\section{Large-scale original symphonic national instrumental drama - Heavenly Tune of Chinese Flute}

In the "Shanghai Spring" International Music Festival, Heavenly Tune of Chinese Flute starred by Tang Junqiao was played, because it not only reproduced the original sound of the bone flute, but also brought a new artistic experience with 
a new performance form of the evolution history of the eight-thousand-year flute to the audiences. The production of this instrumental play adopted a new way, that is, it broke the routine, went across provinces and boundaries, and carried out a win-win cooperation. The art director was Tang Junqiao, who was responsible for all the organization work independently. The whole creative team consists of the middle-aged and young-aged artists. The leading actors of this play are famous Chinese Flute players, including Jiang Guoji (the elder), Wei Sijun (Ling Lun) and so on. Those who participated in the performance also include young conductor Zhao Xiaoou, Chinese Flute orchestra of Shanghai Conservatory of Music, Chinese music department of Shanghai Conservatory of Music, youth symphony orchestra of Shanghai Conservatory of Music, as well as Shanghai Conservatory of Music choir.

\subsection{Innovation of national musical}

"National instrumental musical" is a new genre that breaks through conventions, and connects musical works originally presented in the form of concerts with dramatic narrative clues. It first appeared in the world's first large-scale Chinese instrumental musical Xuanzang's Journey to the West, which was created by the central national orchestra in 2017. In contrast, the musical instruments themselves and music body are the leading characters in the song. Through the long development history of dizi, it described the development process of Chinese civilization. This play's stage design, multimedia design, lighting tone and clothing set off the natural environment, time and season, and the natural and threedimensional stage presents a rich appeal which makes people immersive and memorable.

The music in Heavenly Tune of Chinese Flute is composed of four chapters: Zhu, Zuolv, Zhuyun and Tianlai. The first act is the cooperation of bone flute and Chinese Flute, showing the emptiness of the primitive nature and the individuality of the primitive ancestors incisively and vividly. In the second act, the music is elegant, revealing the lyrical characteristics of a sense of freehand writing. These two chapters focus on the legend of bone flute from savage hunting to "Linglun Zuolv" in the primitive society, and take the "music god" acted by Tang Junqiao as the core character to show the transformation of flute from a tool to an instrument (Zhao, 2019). The third act uses elements of Kunqu opera, so it has unique charm and literati atmosphere, thus forming a sharp contrast to the simplicity and roughness of the first act. The fourth act is an adaptation of composer Guo Wenjing's flute trio Zhuzhici, presented by more than 20 performers from the Chinese Flute orchestra of Shanghai Conservatory of Music. Gorgeous skills sublimed the unique flavor of national music to a new level of modernization.

\subsection{The sounds of nature - "combine false and true, return to original simplicity"}

As a large-scale instrumental musical, the realism and concretization of "drama" are not the focus of creation. Chen Zhiyin wrote in his review that, in this highly abstract auditory art drama, the representational treatment of realism can only be self-defeating. Its originality is to shape characters with instrumental performance, which is coherent and combines virtuality with reality, and shows the barbarism of the primitive ancestors in hunting, the charisma of the music god in rhyme with bamboo, the warm joy shared by gods and goddesses, and the echo of the sounds of nature in the world, to as to present a vague, abstract and ideal theatrical realm. This instrumental work, which is mainly based on performance, needs to return to or go beyond the "Taixu" and "ethereal" freehand meaning in the traditional aesthetics of Taoism in China, which is the foothold and starting point of the creator (Chen Zhiyin, 2018). Only seeing from the Chinese name of the play, diyun tianlai (笛韵天籁), what is “tianlai”? It came from Zhuangzi's On the Equality of Things. The Taoist Zhuangzi believed that "renlai (the sounds of people) " was not as good as "dilai (the sounds of ground)", and "dilai" was not as good as "tianlai". In the Taoist world, tianlai is the highest state of music. The sounds of people is the music played by people with dizi and other silk bamboo. Dilai is the nature sound produced by the wind blowing holes in caves. Tianlai is the sum of the sounds of people and nature. The sounds of the natural world refers to the sound sent out naturally, such as the sound of wind, birds, water and so on. The ultimate ideal pursued by Taoists is the unity of man and nature, in which man should conform to nature, live in harmony with nature, and find beauty in nature.

Through the display of the flute art, Heavenly Tune of Chinese Flute which is a surreal work not only reflects the deep-rooted historical imagination of the ancient culture, but also responds to the current concerns about the environment, social changes, the disappearance of traditional art as well as many other issues. (Rees, 2016).

Public attention is especially important to the development of music art. Thanks to the creation of a number of famous composers and performers, national instrumental musical Heavenly Tune of Chinese Flute is a new and unique art form, and this work has distinctive national temperament and artistic connotation in terms of performance form and music materials. Meanwhile, the content is thick and diversified, and various artistic elements complement each other, so there are very few similar works. Therefore, for the majority of music lovers, Heavenly Tune of Chinese Flute brings them a unique cultural and artistic experience. 


\section{Large-scale humanistic art epic - The Ancient Call}

On January 8, 2017, the large-scale humanistic art epic - Ancient Call, jointly created by professor Zhang Weiliang of the Chinese Conservatory of Music and the Chinese Academy of Culture was played successfully in the National Centre for The Performing Arts. On November 27, 2019, The Ancient Call was played at the Courbevoie Activity Center in Paris, France, and highly praised by the French audiences.

The Ancient Call consists of six parts, including Overture, Dao, Ren, Fa, Yuan and Dream, and it was played by the Chinese Flute orchestra. As for its artistic creation, art director Professor Zhang carried out the conception by centering on the traditional Chinese Confucianism, Buddhism, Taoism culture. Meanwhile, he adopted the manifestation pattern integrating music, drama, martial art, dance, poetry and electronic music together, and used the stage arts effects of staging lighting and multimedia projection to create an immersive experience (Walker, 2018), showing a fantastic and thoughtprovoking Chinese traditional cultural music and art epic for the audiences.

\subsection{Professor Zhang Weiliang's art concept - "the art of Chinese Flute music should adapt to the changes of the times"}

Professor Zhang is a dizi and Xiao player, a member of Chinese Musicians Association, professor of Chinese music department of Chinese Conservatory of Music, vice chairman of Beijing Musicians Association, chairman of Chinese Flute professional committee of Chinese National Orchestral Association, director of Huaxia Chamber Orchestra, vice President of Chinese Orchestra Research Association.

Professor Zhang is one of the musicians who initiated and practiced "xin minyue" in the earliest time. He not only introduced western elements into traditional music, but also created dizi solo and concerto with modern composition techniques. Meanwhile, he constantly expands the creation and expression space of Chinese Flute and explores various possibilities of Chinese Flute ensemble in the new era. Li Xi'an, a professor at the Chinese Conservatory of Music, once appraised Zhang Weiliang's Magic Flute Music like this, "It created a magical music world for people. By virtue of novel creativity and superb acting, the ancient Xiao and flute are endowed with new vigor and vitality, and it created a precedent for the NewAge of the Chinese musical instruments on a high starting point.

The piece of music performed by The Ancient Call has a strong humanistic atmosphere. It is simple and unsophisticated, and at the same time, the integration of electronic band makes the music have a modern spirit. In terms of music, he combined electronic music with traditional Chinese instrumental music, and taking flute and Xiao as the main line, the Chinese national musical instruments including Xun, shakuhachi, Sheng, Guzheng, Guqin, Erhu, Pipa, three-string fiddle, Ruan, China red drum are combined, as well as the textual meaning is interpreted with a rich sense of hearing, thus bringing the audiences a brand new experience (Wang, 2019). Mr. Zhang Weiliang's artistic works are always "keeping pace with the times and innovating". He believes that the nation isn't equal to narrowness, tradition isn't equal to conservativeness, and modernity isn't equal to disorder. Chinese Flute is now at a new height, its reform and development must adapt to the new era of the diversified coexistence as well as diversified music language (Zhang, 2011: P27).

\subsection{Influence of Chinese traditional thought on Chinese Flute}

However, while advocating the modernization of Chinese Flute music and the combination of east and west, Professor Zhang's creative concept always has a humanistic atmosphere of ancient Chinese literature, and he believes that Chinese Flute music is closely related to the philosophy and music of Confucianism, Buddhism and Taoism in Chinese traditional culture.

The Ancient Call is composed of five movements, including Overture, Tao, Ren, Fa, Yuan and Dream, which represent the cosmology of the unity of heaven and man in the Taoist thought; "love the world" in Confucian thought; the truth view of compassion and wisdom in Buddhism, respectively. In Yuan, the composition techniques are organically combined with the spirit of classical Chinese literature to present the all-inclusive, open and inclusive mind of Chinese culture. In the final movement, under the gorgeous stage background, national dance performance artists Ms. Sun Xiaojuan and Mr. Zhu Han headed for the beautiful future like Liang Shanbo and Zhu Yingtai, which indicates the Chinese nation's longing and expectation for beautiful future, so as to demonstrate the value orientation of the Chinese people with traditional Chinese Confucianism, Buddhism, Taoism culture as the core development vein, explore the understanding of human life consciousness in Chinese cultural thought, and arouse the yearning for a better future.

\subsection{Creation significance}

In the epic The Ancient Call, various Chinese cultural elements such as tai chi, kunqu opera and Chinese national dance are integrated into one, which inevitably makes people wonder whether this is a reflection of self-orientalism. However, contrary to this concept, these traditional cultures are inseparable from Chinese traditional thoughts. Famous 
philosopher Jin Yuelin once pointed out that every culture had its core thoughts, every core thought had its most lofty concept and most basic motive force. Chinese traditional culture and thought complement each other. The precipitation of Confucianism, Buddhism and Taoism over the past thousand years can be seen from traditional cultural performance. The artistic concept contained in The Ancient Call expresses Professor Zhang's persistence and belief in a Chinese national art culture (Wang, 2019).

\section{Aesthetic value standards for flute art in the new era}

Since the 1950s, from the founding of the People's Republic of China to the reform and opening up, the development process of Chinese Flute has been advancing with the changes of the society. Professor Zhang holds that the aesthetic appreciation of flute art can be divided into three stages, including appreciation of skills, emotional identification to rational appreciation. The appreciation of skills and emotional identity are the perceptual cognition of art, while the rational appreciation is the aesthetic evaluation of the deep thoughts of the work based on the cognition of the style and type, as well as background culture of the work.

On the contrary, the key to the evaluate the value of artistic works is whether there are profound thoughts in the works and whether they conform to the spirit of the times ( Ji, 2011).

As shown in the legacy of ancient Chinese works of art (such as the traditional Chinese paintings, calligraphy, sculpture) and related literature, the Chinese traditional aesthetic habit and way of thinking are deeply influenced by traditional culture, and traditional Chinese way of thinking is characterized by strong intuition, experience, sensibility, symbol, and the Tao and Zen pursued by the Chinese traditional mainstream culture is a supreme artistic stage, namely, the fusion of situations and the unity of reality and virtuality (Ji, 2011). Although during the war, the development of Chinese music art culture stagnated and even was left behind, but the flute art musicians who sharply rose in the new era seized the cultural essence condensed by the Chinese traditional thoughts and aesthetic habits, made efforts and innovation, and constantly explored and discovered the advantages of predecessors' works, so as to enrich their own artistic cognition and create flute music works with traditional thoughts precipitation and spirit of the time. Therefore, the birth of these new works is not a periodical product, but a collection of reconstructing the interrelationship between music and culture in different dimensions. Therefore, its birth is not accidental, and it is one of the inevitable results of the development of traditional folk music in the new era.

It can be said that The Ancient Call and Heavenly Tune of Chinese Flute, which are two representative works, broke through the performance model of Chinese traditional music, took the stage as a carrier of the ideology of contemporary art, and drew on the wisdom of the masses, brought many outstanding contemporary composers, performers and scholars together to create a multi-angle and all-round audio-visual feast, which is of revelatory significance to the development of contemporary Chinese national music.

\section{References}

[1] The Chinese Bamboo Flute Orchestra. Available from: https://2luck.com/the-chinese-bamboo-flute-orchestra/the-chinese-bamboo-flute-orchestra/

[2] C. Walker. An Introduction to the Chinese Bamboo Flute Orchestra. Available from: https://nmbx.newmusicusa.org/ an-introduction-to-the-chinese-bamboo-flute-orchestra/

[3] Frederick Lau. Forever Red: The Invention of Solo dizi Music in Post-1949 China. British Journal of Ethnomusicology. 1996; 5: 113-131.

[4] Rees Helen. Environmental Crisis, Culture Loss, and a New Musical Aesthetic: China's "Original Ecology Folksongs" in Theory and Practice. Ethnomusicology. 2016; 60(1): 53-88.

[5] Zhang Weiliang. Localization of Musicology: Study on Bamboo Flute Art. Beijing: People's Music Publishing House; 2011.

[6] Zhang Weiliang. Chinese Flute Art and Traditional Chinese Culture: A Study of Bamboo Flute Art. Beijing: People's Music Publishing House; 2011.

[7] Ji Degang. Concrete Image Abstraction - A Brief Discussion on the Title of Works in Music Library of Chinese Contemporary Composers. The Chinese Music. 2011; (2): 172-175.

[8] Wang Meng. National Instrumental Music, Nirvana Rebirth: My Opinions on Ancient Call — A Humanistic Art Epic. Art for the Popular: Academic Edition. 2017; (3): 161-162.

[9] Chen Zhiyin. Tang Junqiao's Heavenly Tune of Chinese Flute. Music Lovers. 2018; (7): 42-47.

[10] Zhao Xiaoou. Experience the Magic of the Heavenly Tune of Chinese Flute. Music Lovers. 2019; (7): 36-39. 